\title{
Front Matter: Volume 10248
}

, "Front Matter: Volume 10248," Proc. SPIE 10248, Nanotechnology VIII, 1024801 (6 July 2017); doi: 10.1117/12.2282027

SPIE. Event: SPIE Microtechnologies, 2017, Barcelona, Spain 


\title{
PROCEEDINGS OF SPIE
}

\section{Nanotechnology VIII}

\author{
Ion M. Tiginyanu \\ Editor \\ 8-9 May 2017 \\ Barcelona, Spain \\ Sponsored by \\ SPIE \\ Cooperating Organisation \\ European Optical Society \\ Published by \\ SPIE
}


The papers in this volume were part of the technical conference cited on the cover and title page. Papers were selected and subject to review by the editors and conference program committee. Some conference presentations may not be available for publication. Additional papers and presentation recordings may be available online in the SPIE Digital Library at SPIEDigitallibrary.org.

The papers reflect the work and thoughts of the authors and are published herein as submitted. The publisher is not responsible for the validity of the information or for any outcomes resulting from reliance thereon.

Please use the following format to cite material from these proceedings:

Author(s), "Title of Paper," in Nanotechnology VIII, edited by lon M. Tiginyanu, Proceedings of SPIE Vol. 10248 (SPIE, Bellingham, WA, 2017) Seven-digit Article CID Number.

ISSN: 0277-786X

ISSN: 1996-756X (electronic)

ISBN: 9781510609976

ISBN: 9781510609983 (electronic)

Published by

SPIE

P.O. Box 10, Bellingham, Washington 98227-0010 USA

Telephone +1 3606763290 (Pacific Time) · Fax +1 3606471445

SPIE.org

Copyright @ 2017 , Society of Photo-Optical Instrumentation Engineers.

Copying of material in this book for internal or personal use, or for the internal or personal use of specific clients, beyond the fair use provisions granted by the U.S. Copyright Law is authorized by SPIE subject to payment of copying fees. The Transactional Reporting Service base fee for this volume is $\$ 18.00$ per article (or portion thereof), which should be paid directly to the Copyright Clearance Center (CCC), 222 Rosewood Drive, Danvers, MA 01923. Payment may also be made electronically through CCC Online at copyright.com. Other copying for republication, resale, advertising or promotion, or any form of systematic or multiple reproduction of any material in this book is prohibited except with permission in writing from the publisher. The CCC fee code is $0277-786 \mathrm{X} / 17 / \$ 18.00$.

Printed in the United States of America.

Publication of record for individual papers is online in the SPIE Digital Library.

\section{SPIE. DIGITAL \\ SPIEDigitalLibrary.org}

Paper Numbering: Proceedings of SPIE follow an e-First publication model. A unique citation identifier (CID) number is assigned to each article at the time of publication. Utilization of CIDs allows articles to be fully citable as soon as they are published online, and connects the same identifier to all online and print versions of the publication. SPIE uses a seven-digit CID article numbering system structured as follows:

- The first five digits correspond to the SPIE volume number.

- The last two digits indicate publication order within the volume using a Base 36 numbering system employing both numerals and letters. These two-number sets start with 00, 01, 02, 03, 04, 05 , $06,07,08,09,0 A, O B \ldots$. OZ, followed by $10-1 Z, 20-2 Z$, etc. The CID Number appears on each page of the manuscript. 


\title{
Contents
}

\author{
$\checkmark \quad$ Authors \\ vii Introduction
}

\section{NANOPLATELETS, NANOTUBES, AND NANOWIRES}

1024805 Tailoring the shape of oxide complex nanostructures [10248-2]

1024808 Large-area fabrication of silicon nanostructures by templated nanoparticle arrays [10248-5]

\section{MULTIFUNCTIONAL APPLICATIONS AND SENSORS}

10248 OE Methanol sensor for integration with GaP nanowire photocathode [10248-11]

10248 OF Nanosensor array systems based on single functional wires selectively integrated and their sensing properties to $\mathrm{C}_{2} \mathrm{H}_{6} \mathrm{O}$ and $\mathrm{NO}_{2}$ [10248-12]

$10248 \mathrm{OH} \quad$ Field emission properties of ring-shaped Si ridges with DLC coating [10248-14]

10248 OK Nano and microcrystallites of $\mathrm{KSbOSiO}_{4}$ in glass matrix as a source of internal strain and fatal corrosion of historic turquoise glass [10248-17]

\section{THIN FILMS AND PHOTOVOLTAICS}

1024800 Silicon-germanium and platinum silicide nanostructures for silicon based photonics [10248-20]

10248 OP Homogeneous fluorescent thin films as long-term stable microscopy reference layers [10248-21]

\section{MATERIAL NANOSTRUCTURING AND MICROFABRICATION}

$102480 Q \quad$ Displacement Talbot lithography: an alternative technique to fabricate nanostructured metamaterials [10248-22]

10248 OR Multilayer porous structures on GaN for the fabrication of Bragg reflectors [10248-23] SYNTHESIS

10248 OW Production of silver nanoparticles by the diatom Phaeodactylum tricornutum [10248-28] 
POSTER SESSION

1024811 Resonant tunneling transport in $\mathrm{Zn}_{\mathbf{x}} \mathrm{Be}_{1-\mathrm{x}} \mathrm{Se} / \mathrm{ZnSe} / \mathrm{Zn}_{\mathrm{y}} \mathrm{Be}_{1-\mathrm{ySe}} \mathrm{Ssymmetric} \mathrm{quantum} \mathrm{structures}$ [10248-34]

1024812 Ultrafast laser patterning of graphene [10248-36] 


\title{
Authors
}

Numbers in the index correspond to the last two digits of the seven-digit citation identifier (CID) article numbering system used in Proceedings of SPIE. The first five digits reflect the volume number. Base 36 numbering is employed for the last two digits and indicates the order of articles within the volume. Numbers start with 00, 01, 02, 03, 04, 05, 06, 07, 08, 09, OA, OB...0Z, followed by 10-1Z, 20-2Z, etc.

\author{
Afanasyev, I. B., OK \\ Al-Daffaie, Shihab, 11 \\ Alonso-Orts, M., 05 \\ Arad (Malis), Shoshana, oW \\ Arapkina, L. V., 00 \\ Balakhnina, I. A., OK \\ Bernard, André, OP \\ Bertke, Maik, 08 \\ Bertsch, Dietmar, OP \\ Bobrinetskiy, Ivan I., 12 \\ Bracht, Hartmut, 08 \\ Brandt, N. N., OK \\ Braniste, Tudor, $O R$ \\ Brülisaver, Martina, OP \\ Çağin, Emine, OP \\ Carlin, Jean-François, OR \\ Chapnin, V. A., 00 \\ Chausse, P. J.P., OQ \\ Chizh, K. V., 00 \\ Chmela, Ondřej, OF \\ Dietrich, Klaus, OP \\ Dubkov, V.P., 00 \\ Eliáš, P., OE \\ Emelianov, Alexey V., 12 \\ Grandjean, Nicolas, OR \\ Hamdana, Gerry, 08 \\ Hartnagel, Hans L., 11 \\ Hasenohrl, S., OE \\ Heeb, Peter, OP \\ Hidalgo, P., 05 \\ Huang, Yifeng, $\mathrm{OH}$ \\ Hubálek, Jaromír, OF \\ Kadikova, I. F., OK \\ Kováč, J., OE \\ Küppers, Franko, 11 \\ Langer, Christoph, $\mathrm{OH}$ \\ Laurenčíková, $\mathrm{A}$., $\mathrm{OE}$ \\ Ławrowski, Robert, $\mathrm{OH}$ \\ Le Boulbar, E. D., OQ \\ Lin, Chih-Lang, 12 \\ Lis, S., $O Q$ \\ López, I., 05 \\ Lüthi, Stefan, OP \\ Martin, Denis, OR \\ Mecani, Mirgen, $\mathrm{OH}$ \\ Méndez, B., 05 \\ Mironov, S. A., 00 \\ Monaico, Eduard, $\mathrm{OR}$ \\ Morozova, E. A., OK
}

\author{
Nogales, E., 05 \\ Novák, J., OE \\ Ong, Duu Sheng, 11 \\ Oprea, Ion, 11 \\ Otero, Nerea, 12 \\ Peiner, Enwin, 08 \\ Piqueras, J., 05 \\ Popa, Veaceslav, OR \\ Prommesberger, Christian, $\mathrm{OH}$ \\ Romano-Rodriguez, Albert, OF \\ Romero, Pablo M., 12 \\ Sadílek, Jakub, OF \\ Samà, Jordi, OF \\ Sanz, A., 05 \\ Schreiner, Rupert, $\mathrm{OH}$ \\ She, Juncong, $\mathrm{OH}$ \\ Shields, P. A., OQ \\ Sirkeli, Vadim P., 11 \\ Stärker, Ulrich, OP \\ Storozhevykh, M. S., 00 \\ Südkamp, Tobias, 08 \\ Tiginyanu, Ion M., OR \\ Ursaki, Veaceslav $V .$, OR \\ Vallejos, Stella, OF \\ Wasisto, Hutomo Suryo, 08 \\ Wishkerman, Asher, OW \\ Yilmazoglu, Oktay, 11 \\ Yuryev, V. A., OK, 00 \\ Yuryeva, T. V., OK
}


Proc. of SPIE Vol. 10248 1024801-6

Downloaded From: https://www.spiedigitallibrary.org/conference-proceedings-of-spie on 26 Apr 2023 Terms of Use: https://www.spiedigitallibrary.org/terms-of-use 


\title{
Conference Committees
}

\author{
Symposium Chair
}

Ulrich Schmid, Technische Universität Wien (Austria)

Symposium Co-chairs

Jacopo lannacci, Findazione Bruno Kessler (Italy)

José Luis Sánchez-Rojas Aldavero, Universidad de Castilla-La Mancha (Spain)

Symposium Local Co-chair

Carles Cané, Centro Nacional de Mircoelectronica (Spain)

Conference Chair

Ion M. Tiginyanu, Academy of Sciences of Moldova (Moldova)

Conference Co-chairs

Rainer Adelung, Christian-Albrechts-Universität zu Kiel (Germany)

Andrei Sarua, University of Bristol (United Kingdom)

Executive Organising Committee

Rainer Adelung, Christian-Albrechts-Universität zu Kiel (Germany) Manuel Delgado-Restituto, Instituto de Microelectrónica de Sevilla (Spain)

Jean-Marc Fédéli, CEA-LETI (France)

Luis Fonseca, Centro Nacional de Microelectrónica (Spain)

loanna Giouroudi, DWI an der RWTH Aachen e.V. (Austria)

Erwin Peiner, Technische Univeristät Braunschweig (Germany)

Mika Prunnila, VTT Technical Research Centre of Finland Ltd. (Finland)

Andrei Sarua, University of Bristol (United Kingdom)

Ion M. Tiginyanu, Academy of Sciences of Moldova (Moldova)

Sander van den Driesche, Universität Bremen (Germany)

Laurent Vivien, Institut d'Électronique Fondamentale (France)

Conference Programme Committee

Necmi Biyikli, Bilkent University (Turkey)

Robert K. Feidenhans'I, University of Copenhagen (Denmark) 
Jochen Feldmann, Ludwig-Maximilians-Universität München

(Germany)

Nicolas Grandjean, Ecole Polytechnique Fédérale de Lausanne

(Switzerland)

Bianchi Méndez, Universidad Complutense de Madrid (Spain)

Arben Merkoçi, Institut Català de Nanotecnologia (Spain)

Hidenori Mimura, Shizuoka University (Japan)

Teresa Monteiro, Universidade de Aveiro (Portugal)

Carlo Ricci, Università degli Studi di Cagliari (Italy)

Ionel-Valentin Vlad, The Romanian Academy (Romania)

Vladimir A. Yuryev, A. M. Prokhorov General Physics Institute (Russian Federation)

Anvar A. Zakhidov, The University of Texas at Dallas (United States)

Anatoly V. Zayats, King's College London (United Kingdom)

\section{Session Chairs}

1 Nanoplatelets, Nanotubes, and Nanowires

Ion M. Tiginyanu, Academy of Sciences of Moldova (Moldova)

2 Luminescence and Light-emitting Devices

Rainer Adelung, Christian-Albrechts-Universität zu Kiel (Germany)

3 Multifunctional Applications and Sensors

Andrei Sarua, University of Bristol (United Kingdom)

4 Thin Films and Photovoltaics

Teresa Monteiro, Universidade de Aveiro (Portugal)

5 Material Nanostructuring and Microfabrication

Hidenori Mimura, Shizuoka University (Japan)

6 Synthesis

Anvar A. Zakhidov, The University of Texas at Dallas (United States) 